\title{
Osteoporosis and HIV Infection
}

\author{
Emmanuel Biver ${ }^{1}[0$
}

Received: 21 December 2021 / Accepted: 6 January 2022 / Published online: 30 January 2022

(c) The Author(s) 2022

\begin{abstract}
Life expectancy of people living with HIV (PLWH) is now close to that of the HIV-uninfected population. As a result, agerelated comorbidities, including osteoporosis, are increasing in PLWH. This narrative review describes the epidemiology of bone fragility in PLWH, changes of bone features over the course of HIV infection and their determinants, as well as the available evidence regarding the management of osteoporosis in PLWH. The risk of fracture is higher and increases about 10 years earlier compared to the general population. The classical risk factors of bone fragility are very widespread and are major determinants of bone health in this population. The majority of bone loss occurs during virus replication and during immune reconstitution at antiretroviral therapies (ART) initiation, which both increase osteoclast activity. Abnormalities in bone formation and mineralization have also been shown in histomorphometric studies in untreated PLWH. Measurement of bone mineral density (BMD) is the first line tool for assessing fracture risk in postmenopausal women, men above 50 years, and other HIV-infected patients with clinical risk factors for osteoporosis. FRAX underestimates fracture probability in PLWH. In case of indication for anti-osteoporotic drug, bisphosphonates remain the reference option. Calcium and vitamin D supplementation should be considered as ART initiation, since it may attenuate bone loss at this stage. Bone-protective ART regimens improve BMD compared to other regimens, but to a lesser extent than bisphosphonate, and without available data on their influence on the incidence of fracture.
\end{abstract}

Keywords Osteoporosis $\cdot$ Fracture $\cdot$ Bone microstructure $\cdot$ HIV $\cdot$ Antiretroviral therapy

\section{Introduction}

With the continuous raising efficacy of antiretroviral therapies (ART) combinations, the characteristics of the HIV population are changing. Life expectancy of people living with HIV (PLWH) is now close to that of the HIV-uninfected population, resulting in PLWH being an aging population, with an increasing proportion of patients over the age of 50, reaching more than 50\% in European countries or in the USA [1, 2].Therefore, PLWH are at greater risk of developing age-related non-communicable diseases, including osteoporosis and fractures, and more attention is needed to prevent or treat these comorbidities [3, 4]. Meanwhile, the majority of PLWH now have an undetectable viral load with stable ART. Bone health in PLWH results from the

Emmanuel Biver

Emmanuel.Biver@hcuge.ch

1 Division of Bone Diseases, Geneva University Hospitals and Faculty of Medicine, University of Geneva, 4 Rue Gabrielle Perret-Gentil, 1205 Geneva, Switzerland complex interactions between aging, comorbidities and classical risk factors affecting bone fragility and very common in this population, and, to a lesser extent, the well-controlled HIV infection itself. This narrative review describes the epidemiology of bone fragility in PLWH, the changes of bone features over the course of HIV infection and their determinants, as well as the available evidence regarding the management of osteoporosis in PLWH.

\section{Epidemiology of Bone Fragility in PLWH}

Meta-analyses have consistently reported a higher fracture risk in PLWH, with an increased risk of fragility fracture of 35 to $68 \%$ compared to the general population (Table 1) [5-11]. This greater risk of fracture occurs with aging of HIV populations and is observed approximately 10 years earlier than in the general population, mainly in middleaged populations such as in the 40-49 and 50-59 age groups [12-14]. In elderly populations, similar hip fracture rates have been reported in nursing home residents in the United 
Table 1 Pooled risk of fractures in meta-analyses of cohorts and case-control studies in PLWH

\begin{tabular}{|c|c|c|c|c|c|c|c|c|c|}
\hline \multirow{2}{*}{$\begin{array}{l}\text { Meta-anal- } \\
\text { yses }\end{array}$} & \multirow{2}{*}{$\begin{array}{l}\text { Number of } \\
\text { studies }\end{array}$} & \multirow[t]{2}{*}{ Pooled risk } & \multicolumn{3}{|l|}{ Any fractures } & \multicolumn{2}{|c|}{ Fragility fractures } & \multirow{2}{*}{$\begin{array}{l}\text { Hip frac- } \\
\text { tures } \\
\text { HIV- } \\
\text { infected vs } \\
\text { non-infected }\end{array}$} & \multirow{2}{*}{$\begin{array}{l}\text { Vertebral } \\
\text { fractures } \\
\text { HIV-infected } \\
\text { vs non- } \\
\text { infected }\end{array}$} \\
\hline & & & $\begin{array}{l}\text { HIV-infected } \\
\text { vs non- } \\
\text { infected }\end{array}$ & $\begin{array}{l}\text { HIV + HCV } \\
\text { co-infected } \\
\text { vs HIV } \\
\text { mono- } \\
\text { infected }\end{array}$ & $\begin{array}{l}\mathrm{HIV}+\mathrm{HCV} \\
\text { co-infected } \\
\text { vs non- } \\
\text { infected }\end{array}$ & $\begin{array}{l}\text { HIV- } \\
\text { infected vs } \\
\text { non-infected }\end{array}$ & $\begin{array}{l}\text { HIV + HCV } \\
\text { co-infected } \\
\text { vs HIV } \\
\text { mono- } \\
\text { infected }\end{array}$ & & \\
\hline $\begin{array}{l}\text { Shiau et al. } \\
\text { [5] }\end{array}$ & $4 / 5$ & IRR & $\begin{array}{l}1.58(1.25, \\
2.00)\end{array}$ & - & - & $\begin{array}{l}1.35(1.10, \\
1.65)\end{array}$ & - & - & - \\
\hline $\begin{array}{l}\text { Dong et al. } \\
\text { [6] }\end{array}$ & $6 / 4 / 3$ & IRR & - & $\begin{array}{l}1.77(1.44, \\
2.18)\end{array}$ & $\begin{array}{c}2.95(2.17, \\
4.01)\end{array}$ & - & $\begin{array}{c}1.70(1.18, \\
2.43)\end{array}$ & - & - \\
\hline $\begin{array}{l}\text { O'Neill et al. } \\
\text { [7] }\end{array}$ & $5 / 2$ & $\mathrm{RR}$ & - & $\begin{array}{c}1.57(1.33, \\
1.86)\end{array}$ & $\begin{array}{c}2.46(1.03, \\
3.88)\end{array}$ & - & - & - & - \\
\hline Ilha et al. [8] & 9 & OR & - & - & - & - & - & - & $\begin{array}{c}2.30(1.37, \\
3.85)\end{array}$ \\
\hline $\begin{array}{l}\text { Pramukti } \\
\text { et al. [9] }\end{array}$ & $\begin{array}{l}7 \\
6\end{array}$ & $\begin{array}{l}\text { OR } \\
\text { IRR }\end{array}$ & $\begin{array}{l}1.91(1.14, \\
3.22) \\
1.50(1.27, \\
1.78)\end{array}$ & - & - & - & - & - & - \\
\hline $\begin{array}{l}\text { Starup- } \\
\text { Linde et al. } \\
{[10]}\end{array}$ & $9 / 6 / 3$ & RR & $\begin{array}{l}1.53(1.46, \\
1.61)\end{array}$ & - & - & $\begin{array}{l}1.51(1.41, \\
1.63)\end{array}$ & - & $\begin{array}{l}4.05(2.99, \\
5.49)\end{array}$ & - \\
\hline $\begin{array}{l}\text { Chang et al. } \\
{[11]}\end{array}$ & $17 / 13 / 6 / 6$ & RR & $\begin{array}{l}1.91(1.46, \\
2.49)\end{array}$ & - & - & $\begin{array}{l}1.68(1.40, \\
2.01)\end{array}$ & - & $\begin{array}{c}1.88(0.99, \\
3.57)\end{array}$ & $\begin{array}{c}1.97(1.22, \\
3.20)\end{array}$ \\
\hline
\end{tabular}

$I R R$ incidence rate ratio, $R R$ relative risk, $O R$ odd ratio, $H I V$ human immunodeficiency virus, $H C V$ hepatitis $\mathrm{C}$ Virus, vs versus

States with and without HIV [15]. The prevalence of vertebral fracture in PLWH varies from 4.1 to $47 \%$ depending on the studies, with a pooled estimated prevalence of $22 \%$ [10]. Co-infections of HIV with hepatitis C or B are associated with a higher risk of fracture than HIV infection alone [6, 7, 16]. Similarly to the general population, incident fractures are associated an increased risk of all-cause mortality in PLWH, but with decreasing associations, likely reflecting advances in HIV care (post-fracture, age- and sex-adjusted all-cause mortality rates per 100 person-year decreased from 8.5 during 2000-2004 to 1.9 during 2013-2017) [17]. In this study, the factors significantly associated with all-cause mortality in PLWH with fractures were the observation period 2000-2004 versus 2005-2017, cardiovascular diseases, chronic kidney diseases, co-infection with hepatitis $\mathrm{C}$, lung disease or a history of non-AIDS cancer.

\section{Bone Characteristics in PLWH}

\section{Bone Mineral Density and Its Changes Over HIV Infection Time-Course}

The prevalence and incidence of osteoporosis in PLWH are increased compared to controls, especially from the fifth decade $[14,18]$. This has been demonstrated in various populations, including women in rural South Africa [19].
The magnitude of the difference of bone mineral density (BMD) between PLWH and controls has been estimated in a meta-analysis to lower BMD Z-scores of -0.36 standard deviations $(95 \% \mathrm{CI}-0.39$ to -0.15$)$ at the spine and -0.31 standard deviations $(-0.46$ to -0.27$)$ at the hip $[10,11]$. In children and adolescents (aged 8-16 years) living with HIV in sub-Saharan Africa, substantial deficits in bone mineral content and density have been reported despite the use of ART. The effect of HIV on BMD was most marked in the late stages of puberty, especially in girls, and with the use of tenofovir disoproxil fumarate (TDF) [20].

However, BMD changes and their magnitude vary over the course of HIV infection [21]. Looking at BMD at the population level in PLWH compared to the uninfected population, BMD is lower even before HIV infection because of the high prevalence of risk factors of osteoporosis in this population (Table 2). Then during untreated HIV infection, BMD decreases due to poor health, weight loss and direct effects of the virus. The greatest decline in BMD is observed after starting ART, for a limited period of 1 to 2 years. Data from the START study clearly demonstrated that bone loss during ART initiation is much greater than that resulting from HIV infection alone [22]. This transient acceleration of bone loss has been attributed to immune reconstitution and is associated with increased bone resorption (via upregulation of the RANKL/OPG pathway), in addition to the specific effects of some drugs on bone metabolism. Greater 
Table 2 Determinants of osteoporosis and fracture in people living with HIV over the time-course of HIV infection

\begin{tabular}{|c|c|c|c|c|}
\hline & $\begin{array}{l}\text { Before HIV } \\
\text { infection }\end{array}$ & $\begin{array}{l}\text { Untreated HIV } \\
\text { infection }\end{array}$ & ART initiation & $\begin{array}{l}\text { Long-term } \\
\text { ART-stable } \\
\text { PLWH }\end{array}$ \\
\hline $\begin{array}{l}\text { Classical risk factors of osteoporosis and fracture } \\
\text { - Non-modifiable: Age, Caucasian ethnicity, prior fractures, parent history } \\
\text { of hip fracture } \\
\text { - Modifiable: Low BMI, lifestyle: tobacco, alcohol, low physical activity, } \\
\text { poor nutrition: low calcium and protein intakes, vitamin D deficiency, } \\
\text { hypogonadism in men and early menopause, comorbidities and drugs } \\
\text { (glucocorticoids), fall risk }\end{array}$ & ++ & ++ & ++ & ++ \\
\hline $\begin{array}{l}\text { Immune and bone cell HIV infection } \\
\text { - Increased osteoclasts differentiation and activity } \\
\text { - Decrease osteoblast activity } \\
\text { - Pro-adipogenic and inflammatory environment } \\
\text { - Immune system modulation }\end{array}$ & $\mathbf{0}$ & ++ & +++ & $\mathbf{0}$ \\
\hline $\begin{array}{l}\text { Direct effect of ART } \\
\text { - Renal tubulopathy and urine phosphate wasting (tenofovir) } \\
\text { - Interaction with vitamin D metabolism }\end{array}$ & $\mathbf{0}$ & + & + & + \\
\hline $\begin{array}{l}\text { Gut microbial dysbiosis } \\
\text { - HIV-induced gut dysbiosis promoting pro-inflammatory environment } \\
\text { - ART effects on gut microbiota }\end{array}$ & $0 /+$ & +++ & ++ & + \\
\hline BMD changes & $\leftrightarrow \backslash \searrow$ & $\searrow \searrow$ & $\searrow \searrow \searrow$ & $\leftrightarrow \backslash \searrow$ \\
\hline
\end{tabular}

The respective contribution of each determinant block at the population level is indicated $(0$, no contribution, + low, ++ medium, +++ high $)$, and may vary at patient individual levels. Some classical risk factors may be corrected (diet improvement, stop tobacco or alcohol, increase physical activity) while others appears (aging, hypogonadism, comorbidities) in long-term ART-stable PLWH

$H I V$ human immunodeficiency virus, $A R T$ antiretroviral therapy; $P L W H$ people living with HIV, BMD bone mineral density

decreases in BMD have been reported between baseline and 2 years in PLWH after initiation of TDF-based ART compared to non-TDF-ART [23, 24]. The magnitude of bone loss exceeds that seen after menopause, or approaches that observed during treatment with glucocorticoids or aromatase inhibitors, only within 1-2 years following ART initiation (Fig. 1). Finally, with long-term ART and suppression of viral activity, BMD may increase and then stabilizes. In long-term HIV-positive elderly men aged 60-70 on successful ART for 15 years (median), areal BMD at various bone sites was only 3 to $8 \%$ lower than in HIV-negative men matched for age and BMI [25].

\section{Bone Microstructure}

Bone microstructure has also been investigated in PLWH using high-resolution peripheral QCT in several crosssectional studies, in patients of various age, sex and duration of ART [25, 33-37]. Overall, these data indicate that alterations in volumetric BMD and bone microarchitecture predominate in trabecular rather than cortical bone compartments, except in young and elderly patients in whom defects of cortical thickness or area have also been observed (Fig. 2). The magnitude of the differences in bone traits compared with the respective non-HIV-infected control groups did not exceed $20 \%$ at any time and tended to attenuate with aging and duration of ART.

\section{Bone Histomorphometry}

Bone histomorphometry using tetracycline double-labeled transiliac crest biopsies has been reported in two studies: the first one in ART-naïve men and women in the 1990s, including $50 \%$ of patients with AIDS-defining opportunistic infections; and a recent one in ART-naïve men who underwent paired biopsies before and 12 months after initiation of TDF/lamivudine/efavirenz (Table 3) [38, 39]. Overall, these data indicate low bone turnover with primarily abnormalities in bone formation and mineralization which are present in untreated PLWH with and without advanced HIV. With ART, there is an increase in bone remodeling but a persistence of the mineralization defect, resulting in an increase in osteoid volume. The decrease in mineralization was not attributable to vitamin D deficiency in these studies. There were no significant change in renal phosphate excretion nor in mineralization parameters with initiation of TDF-containing ART.

\section{Pathophysiology and Risk Factors of Osteoporosis and Bone Fragility in PLWH}

Several factors can affect bone fragility and the risk of falls in PLWH, leading to a higher risk of fractures. These factors are linked to the patient himself and to the classical risk 


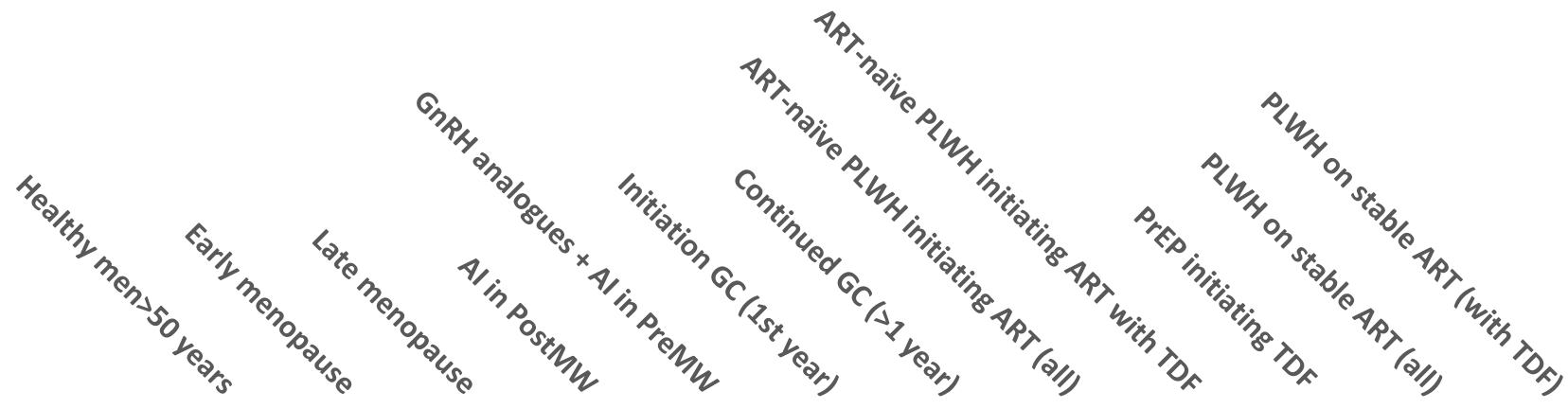

$2 \%$

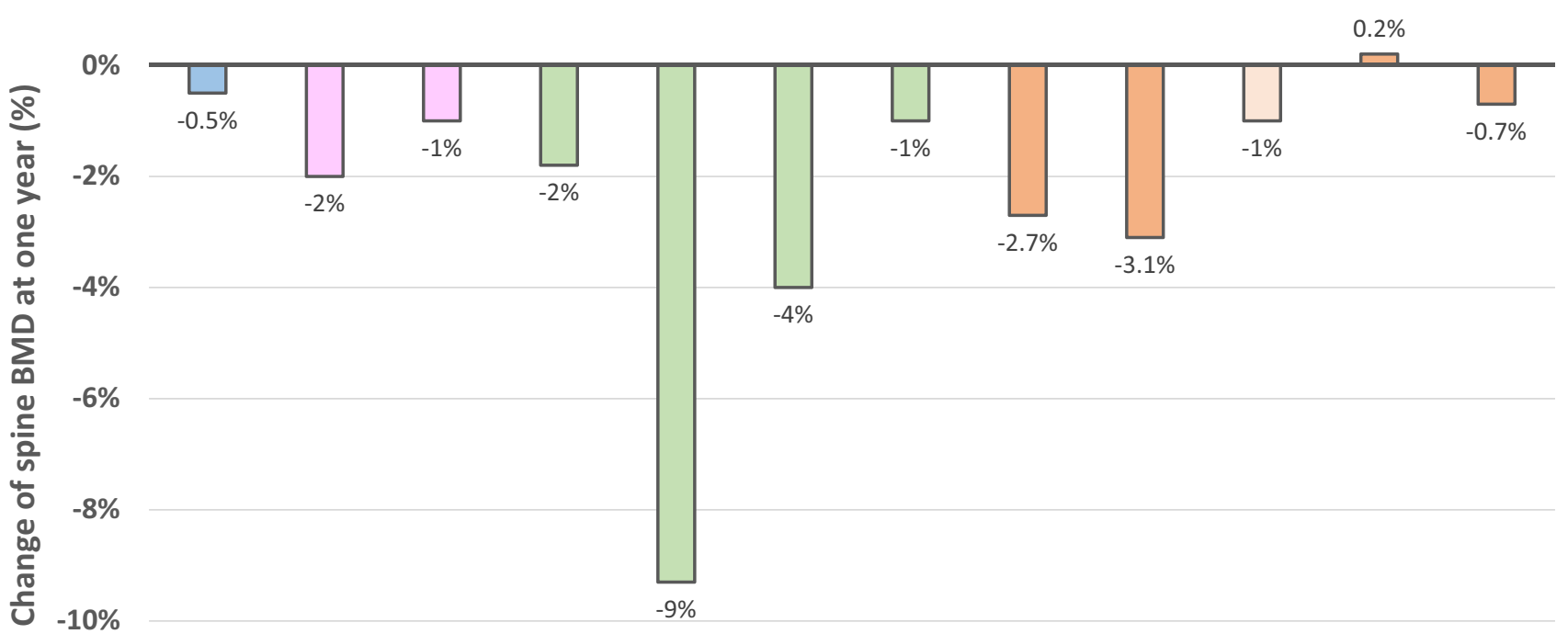

Fig. 1 Change of spine BMD after one year in various conditions including HIV. Adapted from Refs. [10, 26-32]. AI aromatase inhibitor, PostMW postmenopausal women, PreMW, premenopausal women, GnRH Gonadotropin-Releasing Hormone, GC glucocorti-

factors for fractures which are very common in this population, to factors linked to viral activity and also to the effect of ART [40].

\section{Contribution of Classical Risk Factors of Bone Fragility}

The risk factors of osteoporosis and bone fragility in PLWH are summarized in Table 2. Traditional risk factors include age, low BMI, nutritional factors, toxic habits, as well as hypogonadism. The prevalence of hypogonadism is high in HIV-positive men, approximately $20 \%$ of them. It can be primary hypogonadism, but also secondary hypogonadism associated with hypothalamus and pituitary axis dysfunction, obesity, metabolic syndrome or lipodystrophy [41]. In women, HIV infection and menopause are independent predictors of a decrease of BMD [42]. In adults infected with HIV, malnutrition and reduced frequency of mechanical loading activities have been associated with alterations coids, ART antiretroviral treatment, PLWH people living with HIV, $T D F$ tenofovir disoproxil fumarate, $\operatorname{PrEP}$ HIV pre-exposure prophylaxis

in bone microstructure [43]. The combination of several of these risk factors in patients co-infected with HIV and hepatitis $\mathrm{C}$ could explain the particularly increased risk of fractures in this population. Serious falls within the past year, significant enough to warrant a visit to a health care provider, are also, as in the general population, strong predictors of fragility fractures in PLWH on ART [44].

\section{Virus Activity}

Bone loss is accelerated in patients with a high viral load, suggesting a direct effect of virus activity and systemic inflammation on bone metabolism. Recent data demonstrated that HIV has various direct effects on bone cells. HIV affects not only lymphocytes, but also macrophages and osteoclasts via cell-free viruses or by cell-to-cell transfer from infected T-cells. By secreting the receptor activator of nuclear factor kappa-B ligand (RANK-L) and reducing the expression of osteoprotegerin, HIV-infected lymphocytes 


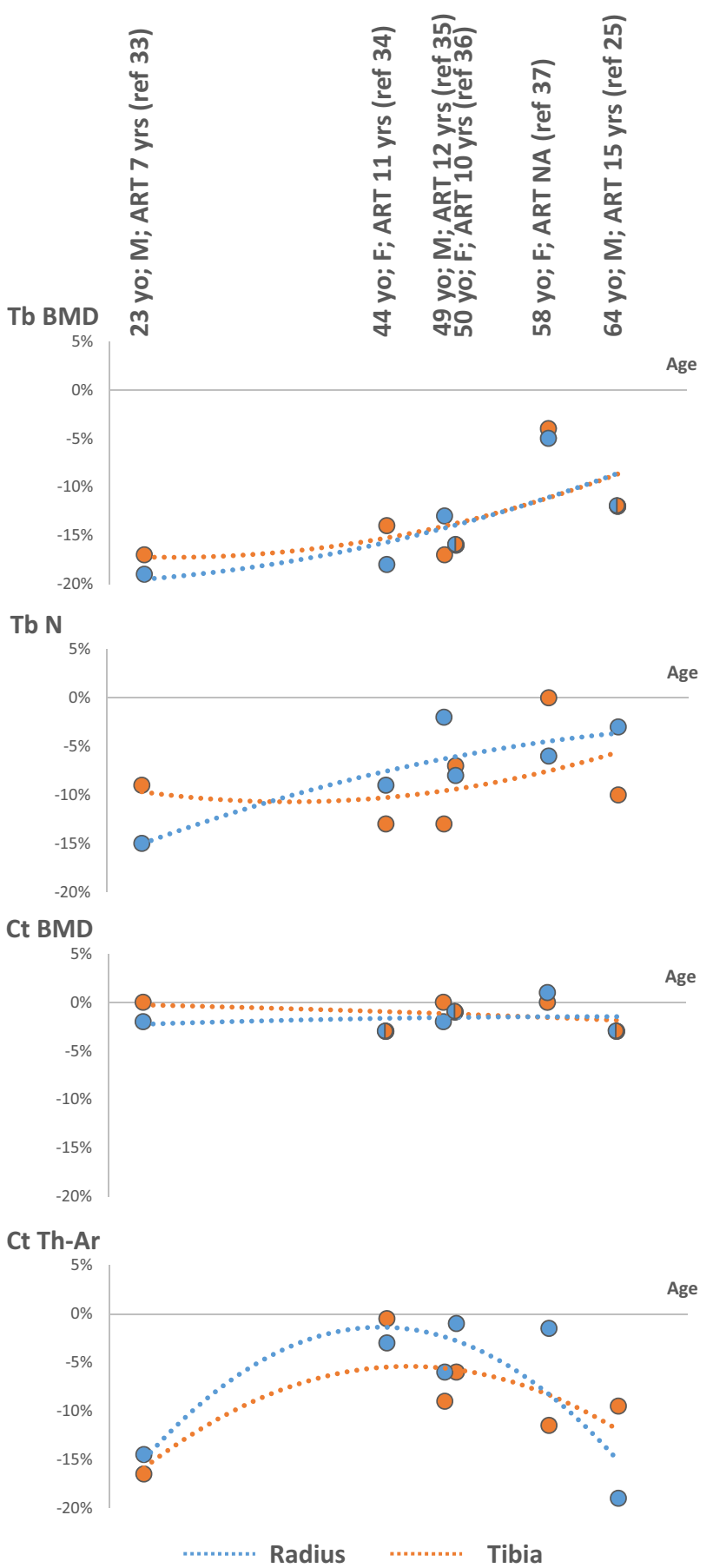

Fig. 2 Difference (\%) in trabecular and cortical BMD and microarchitecture at the distal radius and tibia between HIV and controls groups in cross-sectional studies, according to age. Sex of the study populations and duration of ART use are indicated (when available). Adapted from Refs. [25, 33-37]. $M$ men, $F$ women, $A R T$ antiretroviral therapy, yo years old, yrs years, $T b$ trabecular, $C t$ cortical, $B M D$ bone mineral density, $N$ number, $A r$ area, $T h$ thickness, $N A$ not available and macrophages help create a microenvironment that promotes the recruitment of osteoclasts [45]. In addition, in osteoclasts infected with HIV, the expressions of RANKL, tartrate-resistant acidic phosphatase (TRAP) and cathepsin $\mathrm{K}$ are increased. These effects, dependent on viral proteins such as Nef or Tat, result in more numerous and more osteolytic osteoclasts having larger and denser sealing zones [46, 47]. HIV also induces early senescence of bone marrow MSCs, the precursors of osteoblasts, and stimulates these cells to secrete inflammatory cytokines such as IL-6 and IL-8. Osteoblast apoptosis is stimulated and the expression of pro-osteoblastic factors such as alkaline phosphatase, runt-related transcription factor 2 (RUNX-2), bone morphogenic proteins (BMP-2, BMP-7) or osteocalcin is decreased. Meanwhile, some viral proteins induce the expression of peroxisome proliferator-activated receptor $\gamma$ (PPAR $\gamma)$. All these factors contribute to a proadipogenic rather than proosteogenic phenotype (Table 2) [46].

\section{Antiretroviral Treatments}

ART also affects bone health, independently of the indirect and transient decrease in BMD observed after the start of any ART regimen, associated with immune reconstitution (Table 2) $[48,49]$. This has been particularly demonstrated with TDF. A meta-analysis showed that PLWH on stable ART only lose bone with TDF-containing ART (Fig. 1) [10]. Another tenofovir prodrug, tenofovir alafenamide has been developed. Due to specific intracellular activation of the prodrug in infected immune cells, circulating tenofovir concentrations are lower with TAF and a lower BMD decrease is observed with TAF than with TDF. The effect of TDF on bone metabolism is at least partly independent of the context of HIV infection since the decrease of BMD has also been reported, compared to placebo or TAF, in the context of HIV pre-exposure prophylaxis (PrEP) [50, 51]. However, the magnitude of bone loss in these studies appears to be lower than in PLWH (0.8\% to 1\% BMD loss at the spine after 1 year) (Fig. 1). A meta-analysis of randomized controlled trials evaluating the different impacts of various ART on BMD in PLWH showed that loss of BMD was significantly attenuated with abacavir or TAF compared to TDF. After 96 weeks, spine and hip BMD were significantly less reduced with abacavir compared to TDF by 1.37 percentage point (pp) $(95 \%$ CI $0.58,2.15)$ and $1.40 \mathrm{pp}(0.75,2.05)$, respectively; with TAF compared to TDF by $1.90 \mathrm{pp}(1.65,2.15)$ and $2.66 \mathrm{pp}(95 \%$ CI 2.52 to 2.79), respectively [10]. In virologically supressed PLWH, 
Table 3 Bone histomorphometry studies using tetracycline double-labeled transiliac crest biopsies in people living with HIV

\begin{tabular}{|c|c|c|c|}
\hline Reference & Serrano S et al., 1995 [38] & \multicolumn{2}{|l|}{ Ramalho J et al., 2019 [39] } \\
\hline \multicolumn{4}{|l|}{ Study characteristics } \\
\hline Study population & $\begin{array}{l}\text { ART-naïve patients, age } \\
27.9 \pm 4.1 \text { years, } 59 \% \text { men, low } \\
\text { BMI, } 73 \% \text { intravenous drug abus- } \\
\text { ers, } 50 \% \text { alcohol }>20 \text { g/day, } 50 \% \\
\text { with AIDS-defining opportunistic } \\
\text { infections }\end{array}$ & \multicolumn{2}{|c|}{$\begin{array}{l}\text { ART-naïve patients, age } 29.6 \pm 5.5 \text { years, } 100 \% \text { men, normal BMI } \\
\quad(24.7 \pm 2.4 \mathrm{~kg} / \mathrm{m} 2), 5 \% \text { alcohol }>30 \mathrm{~g} / \mathrm{d}\end{array}$} \\
\hline Study years and setting & Before 1995, Barcelona, Spain & \multicolumn{2}{|l|}{ 2015- 2016, Sao Paulo, Brazil, } \\
\hline Biopsy timepoint & Before ART initiation & Before ART initiation & 12 months after ART initiation \\
\hline Number of patients & 22 & 20 & 16 \\
\hline $25 \mathrm{OH}$ vitamine $\mathrm{D}(\mathrm{ng} / \mathrm{mL})$ & $16.5 \pm 9.6$ & $22.0 \pm 7.0$ & $27.7 \pm 8.7$ \\
\hline Parathyroid hormone (pg/mL) & $18.7 \pm 5.3$ & $31.3 \pm 9.2$ & $41.4 \pm 12.4$ \\
\hline \multicolumn{4}{|l|}{ Static parameters } \\
\hline Structural cortical parameters & Not provided & Cortical thickness \in $25 \%$ & $\nearrow$ Cortical thickness by $37 \%$ \\
\hline Structural trabecular parameters & $\begin{array}{l}\text { Normal trabecular volume, number } \\
\text { and thickness, } \uparrow \text { trabecular } \\
\text { separation }\end{array}$ & $\begin{array}{l}\text { Bone volume/tissue volume } \searrow \text { in } \\
20 \%\end{array}$ & No change \\
\hline Bone formation parameters & $\begin{array}{l}\searrow \text { Osteoid volume, surface and } \\
\text { thickness }\end{array}$ & Osteoid thickness \in $50 \%$ & $\begin{array}{l}\nearrow \text { Osteoid volume }(+185 \%, \text { still } \\
\text { within the reference range), and } \\
\text { osteoblast surface/bone surface } \\
\text { (+234\% increase, to values } \\
\text { above the normal ranges) }\end{array}$ \\
\hline Bone resorption parameters & $\begin{array}{l}\searrow \text { Osteoclast number and eroded } \\
\text { surface }\end{array}$ & $\begin{array}{l}\text { Osteoclast surface and eroded } \\
\text { surface } \nearrow \text { in } 30-40 \%\end{array}$ & $\begin{array}{l}\nearrow \text { osteoclast surface/bone surface } \\
(+121 \%, \text { to values above the } \\
\text { normal ranges })\end{array}$ \\
\hline \multicolumn{4}{|l|}{ Dynamic parameters } \\
\hline Bone formation rate & $\searrow$ & $\searrow$ in $80 \%$ & No change \\
\hline Mineralization & $\searrow$ & $\searrow$ in $60 \%$ & No change \\
\hline
\end{tabular}

$A R T$ antiretroviral therapy

the decrease in BMD induced by TDF is also attenuated by switching to TAF or to another regimen including abacavir or an integrase inhibitor [52,53]. In these switch studies, BMD remained stable in control groups that continued TDF-containing ART, confirming the lack of significant effect on BMD of stable TDF-ART regimen in virologically suppressed PLWH, and increased by $1-2 \%$ after one year in the switched groups. Whether this BMD gain is transient or continues over time is not established.

TDF is also associated in some patients with proximal renal tubulopathy and urine phosphate wasting, which appear to be related to cumulative exposure to TDF, and may persist even after discontinuation of TDF [54]. The pathophysiology of these tubulopathies remains unclear. In addition, the development of hypophosphatemia and osteomalacia is very rare and bone biopsy data reported earlier in the manuscript did not reveal worsening of mineralization with initiation of TDF [39]. The risk of developing tubulopathy seems to be lower with TAF [55].

\section{Contribution of Gut Microbiome}

Another emerging area in the field of HIV and its impact on bone is the contribution of gut microbial dysbiosis, which affects immune function and HIV persistence (Table 2). Chronic HIV infection induces microbial dysbiosis in the gut, resulting in an overall decrease in microbiome diversity and functional capacity. This dysbiosis leads to an increase of the permeability of the gut barrier which adds to the depletion of T-cells induced by HIV in gut-associated lymphoid tissue, and induces an innate immune activation, resulting in a shift toward a proinflammatory cytokine environment with osteoclastogenesis and bone resorption enhancement [56]. In addition to sexual behavior and/or HIV infection, ART also influences the composition of the gut microbiota in PLWH, which changes before and after the start of ART. This has been shown in PLWH and in the context of PrEP and may affect bone health, as demonstrated in the non-HIV population 
[57-60]. The impact on fecal microbial diversity, which potentially causes intestinal dysbiosis, has been particularly observed in patients receiving ART including nucleotide/nucleoside reverse transcriptase inhibitor (NRTI), with a propensity for intestinal microbiota enriched in Prevotella and poor in Bacteroides [57]. In vitro studies have indicated that zidovudine (AZT), one of NRTI, exhibits antibacterial effects, suggesting potential direct effects on gut microbiota [61]. To what extent targeting gut dysbiosis in ART-stable PLWH could help improve calcium balance and attenuate bone loss remains unexplored.

\section{Prevention and Management of Osteoporosis in PLWH}

\section{General Preventive and Screening Measures}

A periodic assessment of clinical risk factors for bone fragility is recommended in all PLWH, with the implementation of general preventive measures such as the promotion of physical activity, a balanced diet, the cessation of toxic habits when applicable, and prevention of fall in elderly patients.

A DXA scan is recommended for all postmenopausal women, men above 50 years of age, and patients with other clinical risk for fragility fractures, since these patients are more likely to benefit from anti-osteoporotic drugs in case of low BMD [62]. Although the FRAX® tool has been recommended for routine assessment of fracture risk in PLWH over 40 years of age in some guidelines [63], it underestimates fracture risk in PLWH, even including HIV to the set of secondary risks for osteoporosis or after adjustment for the trabecular bone score (TBS). The ratio of observed to predicted fractures is greater than 3 under all of these conditions, possibly because important factors associated with HIV infection are not adequately captured by the tool $[64,65]$. Therefore, FRAX should not be considered as a fist-line screening tool for bone fragility in PLWH but may potentially help for decision on intervention with anti-osteoporotic drugs in case of moderately decreased BMD.

\section{Calcium and Vitamin D}

The prevalence of vitamin $D$ insufficiency, i.e. serum $25-\mathrm{OH}$ vitamin $D<50 \mathrm{nmol} / \mathrm{L}(20 \mathrm{ng} / \mathrm{mL})$, is high in PLWH, up to $80 \%$ in HIV cohorts [66]. The lastest guidelines of the European AIDS Clinical Society (EACS) recommend checking vitamin D status in PLWH with history of low BMD and/or fracture, high risk for fracture, or with other factors associated with lower vitamin D levels (dark skin, dietary deficiency, avoidance of sun exposure, malabsorption, obesity, chronic kidney disease, and use of efavirenz or protease inhibitors) [67]. A review of 29 clinical studies of vitamin D supplementation in PLWH showed that there is a decrease in inflammation, bone turnover markers, and secondary hyperparathyroidism when vitamin D levels are increased to optimal values regardless of ART [68].

Interventions studies with vitamin D or calcium/vitamin D supplements on bone in PLWH are summarized in Table 4. These studies were performed in children, adolescent or young adults $(n=7)$ or in adults $(n=3)$, with various supplementation regimens regarding the dose and frequency of administration. The equivalent daily doses, calculated according to the doses used in each trial, ranged from approximately 1100 to 7000 IU, thus higher than the daily or equivalent daily dose of 800 UI of vitamin D recommended for maintaining bone health in the elderly and postmenopausal women uninfected with HIV [69]. A decrease of parathyroid hormone (PTH) or bone turnover markers has been observed in some studies [70, 71]. BMD was investigated in 7 studies, with 2 of them showing trends for benefit on BMD in youth [72, 73]. Interestingly, a smaller decrease in hip and spine BMD has been reported, compared to placebo, in ART-naïve adults supplemented with calcium (1000 mg/day) and high-dose of vitamin D (4000 IU/day) at initiation of efavirenz/ emtricitabine/TDF [74]. These data are consistent with the pre-existing defect in bone mineralization reported in histomorphometric studies [38, 39]. Since loss of bone mass at ART initiation can be alleviated with vitamin D and calcium supplements, intervention with supplements should be considered early as the initiation of HIV infection management, in case of low calcium dietary intake and low vitamin levels. A specific emphasis on vitamin $\mathrm{D}$ in PLWH is important since efavirenz, a non-nucleoside reverse transcriptase inhibitor, has been associated with lower vitamin D levels via a modulation of various cytochromes and enzymes involved in activation or deactivation of vitamin $\mathrm{D}$ or vitamin D-binding protein $[75,76]$. It is not established whether the optimal vitamin D dosage regimen should differ in PLWH compared to the general population, and the EACS guidelines recommend maintenance with 800 to 2000 IU of vitamin D per day [67]. Vitamin D should be combined with calcium in patients with insufficient dietary calcium intake.

\section{Anti-osteoporotic Drugs}

In patients with osteoporosis, bisphosphonates remain first line options in PLWH because clinical data suggest that they are well tolerated, safe, and with BMD response similar to that of the general population (Table 5). The effects 


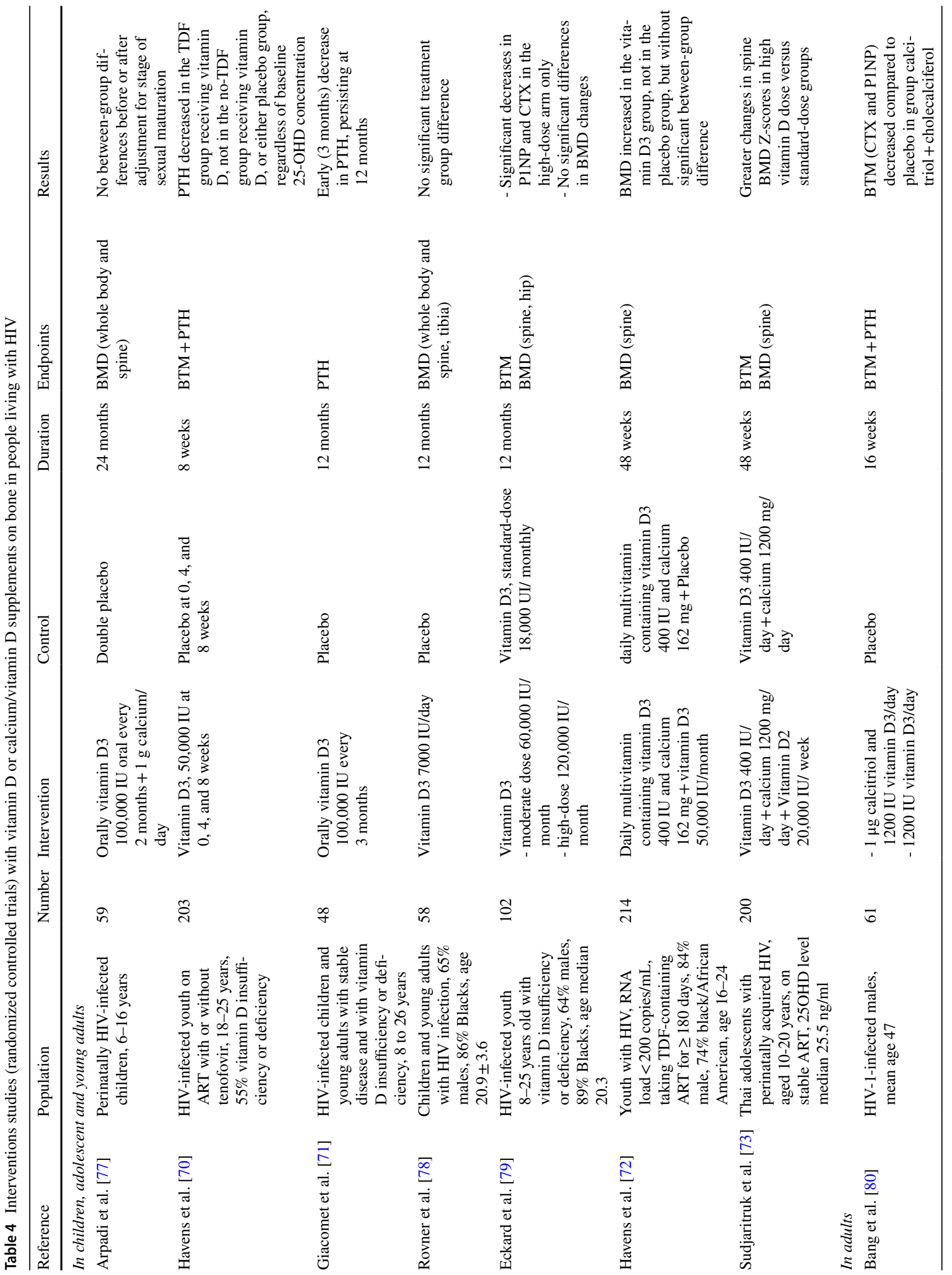




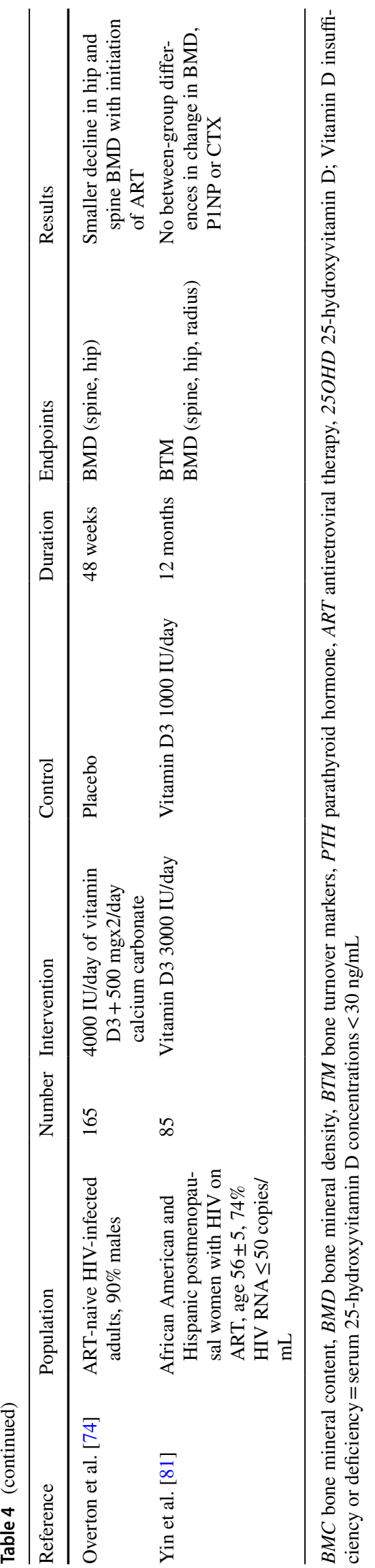

of zoledronic acid persist for several years after one or two infusions $[82,83]$. A single dose of zoledronic acid in nonosteoporotic, ART-naïve, HIV-infected adults initiating ART prevents the decrease of BMD [84]. A short-course of oral alendronate, started 2 weeks prior the initiation of ART and continued for a total of 14 weeks, also attenuates BMD decrease in this context [85]. There is no evidence that HIV patients are at greater risk for bisphosphonate-associated osteonecrosis of the jaw or atypical femoral fractures. For other anti-osteoporotic treatments such as denosumab or teriparatide, data are currently lacking, with only a few case reports or cohort studies [86].

\section{ART Regimen in Case of Bone Fragility}

It has been suggested to consider or switch to "bonefriendly" ART to reduce bone loss in PLWH with established osteoporosis or multiple risk factors for developing bone fragility. TDF-sparing regimens using TAF or integrase inhibitor are also discussed in the context of renal toxicity associated with bone fragility, or renal hypophosphatemia $[62,63]$. However, there is currently no data showing that initiating, or switching to a bone-protective ART regimen reduces the incidence of fracture in PLWH. The magnitude of BMD improvement is lower in patients switching from TDF to abacavir or integrase inhibitors compared to one shot of $5 \mathrm{mg}$ zoledronic acid added to TDF in virologically suppressed HIV-infected adults [97, 98]. Real-world data have also indicated that combining bisphosphonates with stopping TDF results in greater improvements in BMD than stopping TDF alone [99]. Therefore, it may also be necessary to consider anti-osteoporotic drugs in case of osteoporosis or high risk of fracture, even if a switch to a bone-friendly ART regimen has been done. Another point to consider is the substantial greater bodyweight gain observed in PLWH receiving TAF, or to a lower extent an integrase inhibitor, compared to TDF [100]. Replacing TDF with TAF is also associated with weight gain, development of obesity and worsening serum lipid levels [101]. To what extent these changes of fat mass contribute to the increase of BMD or attenuation of bone loss observed with TAF or integrase inhibitors remains unexplored.

\section{Conclusion}

HIV infection has direct and indirect effects on bone metabolism, characterized by abnormalities in bone formation and mineralization in untreated PLWH, and increased of bone resorption with initiation of ART and associated immune reconstitution. In ART-stable patients, BMD does not decrease more than in the general population, except in the 


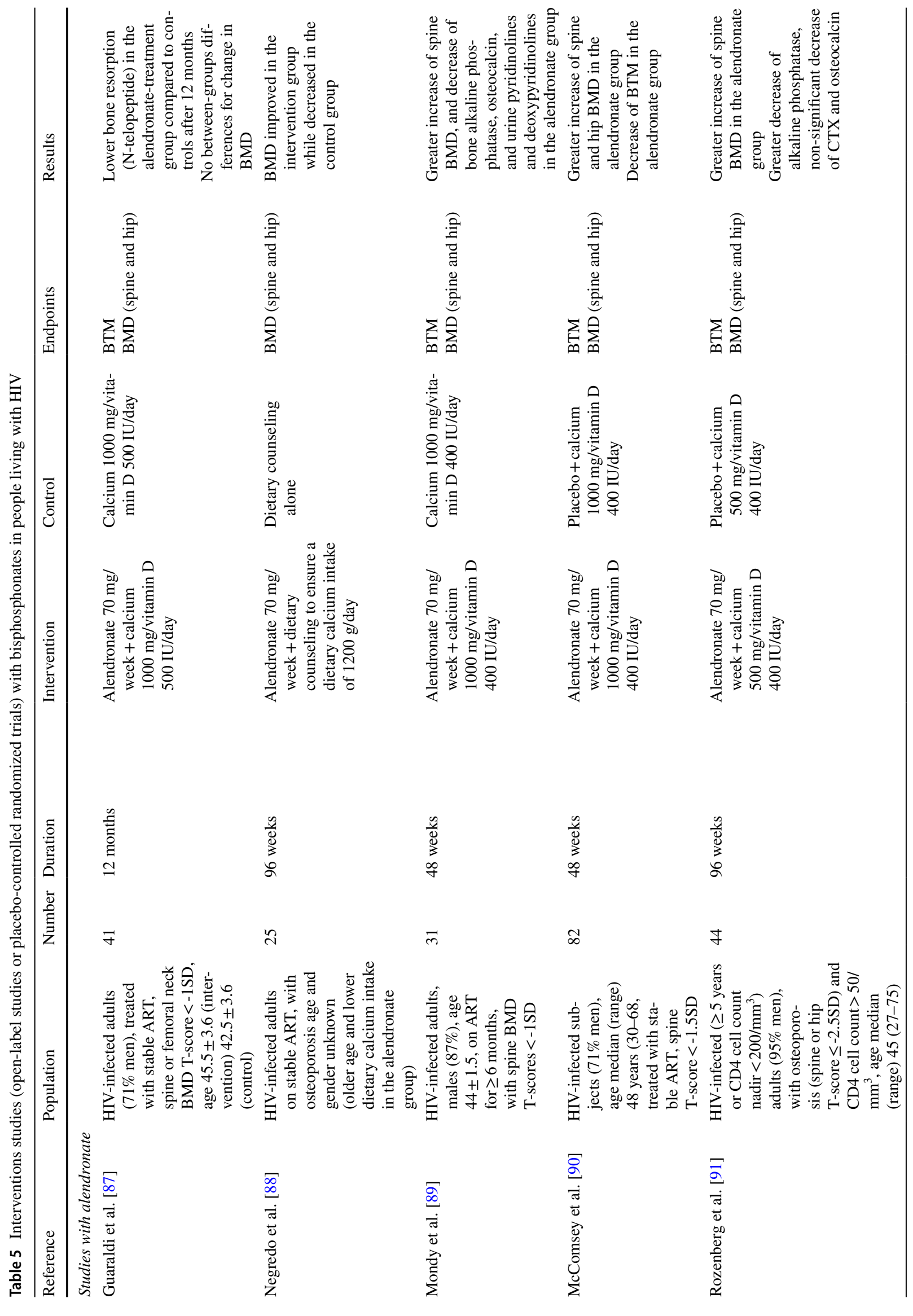




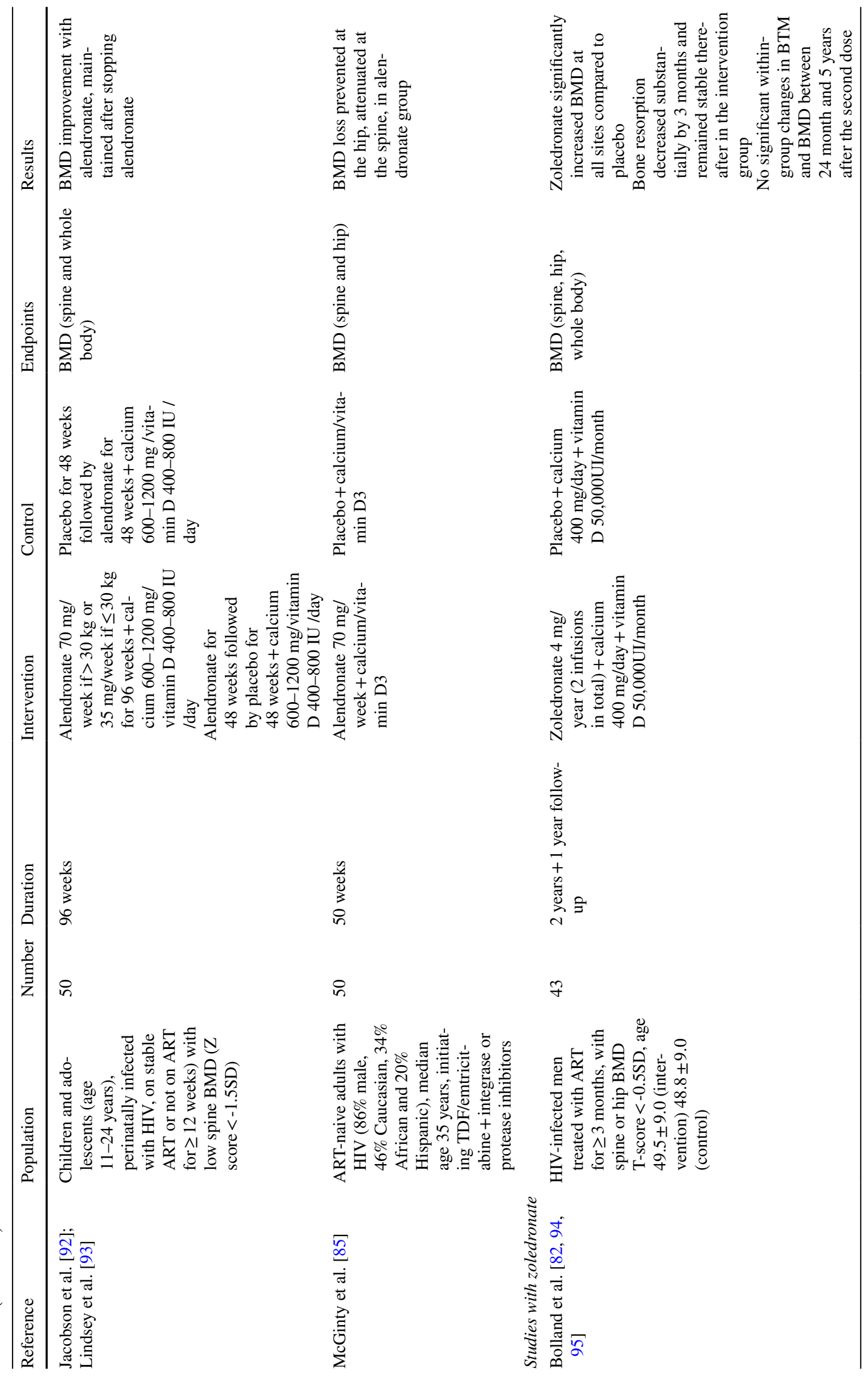




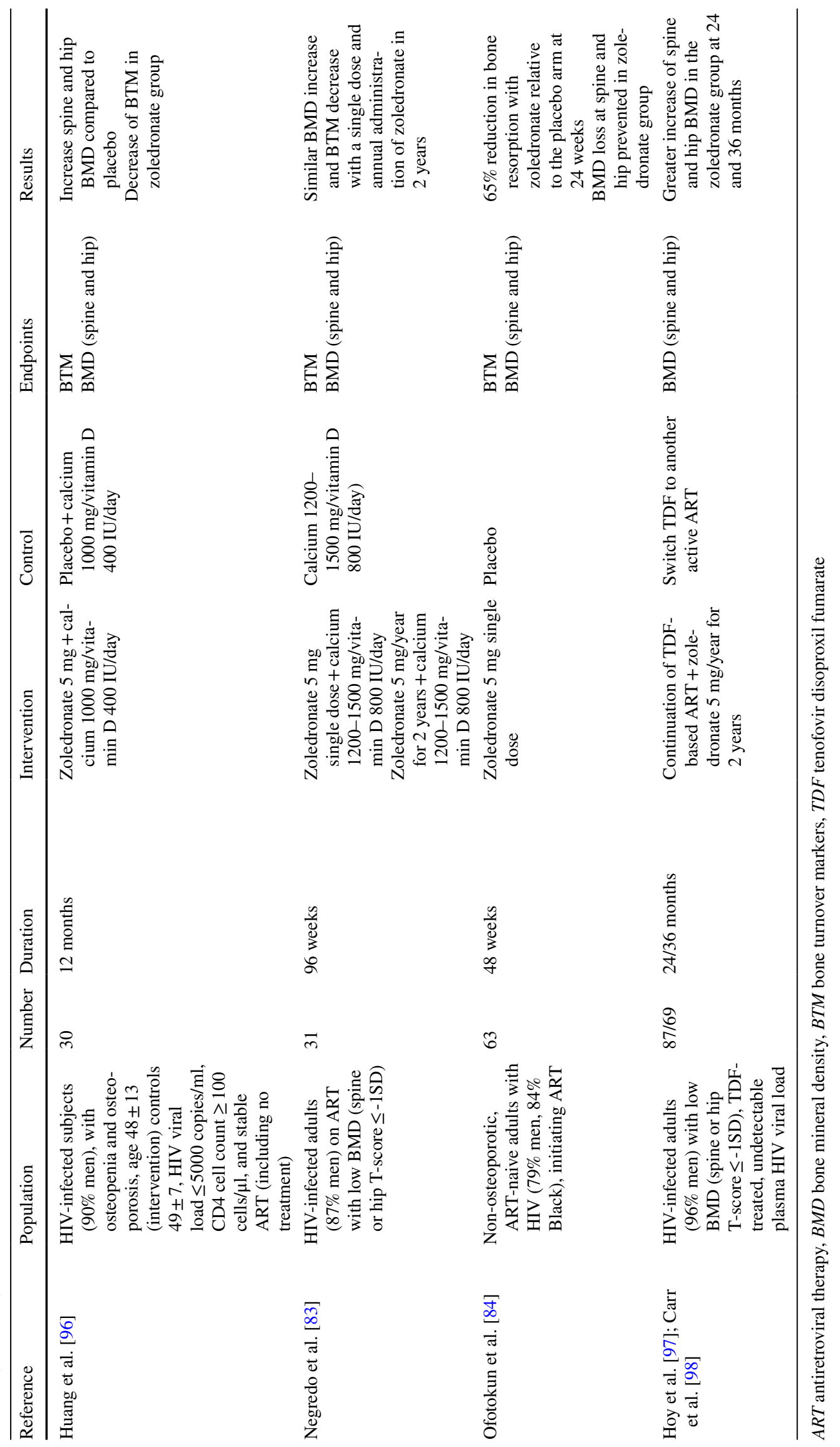


presence of classical risk factors for osteoporosis, which are very common in PLWH and should be regularly assessed. Therefore, epidemiological studies have shown that the risk of fracture is higher in PLWH than in the HIV-negative population, and even higher in case of co-infection with hepatitis C. Fractures tend to occur approximately 10 years earlier in PLWH than in the general population. HIV infection itself and the type of ART regimen (especially TDF) contribute to bone loss. Reducing tenofovir plasma concentrations with TAF attenuates the decrease of BMD, but it remains unknown whether it will contribute to reduce fracture risk. Calcium and vitamin D supplementation should be considered as ART initiation, since it attenuates the decrease of BMD at this stage. In case of indication for anti-osteoporotic drug, bisphosphonates remain the reference option.

Acknowledgements The author thanks Pr Alexandra Calmy and Dr Maxime Hentzien, from the division of Infectious Diseases, HIV-AIDS Unit, Geneva University Hospitals, Switzerland, for helpful discussions and for reviewing the draft of the review.

Funding Open access funding provided by University of Geneva.

\section{Declarations}

Conflict of interest The author has no relevant financial or non-financial interests to disclose.

Open Access This article is licensed under a Creative Commons Attribution 4.0 International License, which permits use, sharing, adaptation, distribution and reproduction in any medium or format, as long as you give appropriate credit to the original author(s) and the source, provide a link to the Creative Commons licence, and indicate if changes were made. The images or other third party material in this article are included in the article's Creative Commons licence, unless indicated otherwise in a credit line to the material. If material is not included in the article's Creative Commons licence and your intended use is not permitted by statutory regulation or exceeds the permitted use, you will need to obtain permission directly from the copyright holder. To view a copy of this licence, visit http://creativecommons.org/licenses/by/4.0/.

\section{References}

1. Scherrer AU, Traytel A, Braun DL, Calmy A, Battegay M, Cavassini M et al (2021) Cohort profile update: the Swiss HIV Cohort Study (SHCS). Int J Epidemiol. https://doi.org/10.1093/ ije/dyab141

2. Alvarez E, Belloso WH, Boyd MA, Inkaya A, Hsieh E, Kambugu A et al (2016) Which HIV patients should be screened for osteoporosis: an international perspective. Curr Opin HIV AIDS 11(3):268-276. https://doi.org/10.1097/coh.0000000000000269

3. Kim JH, Noh J, Kim W, Seong H, Kim JH, Lee WJ et al (2021) Trends of age-related non-communicable diseases in people living with HIV and comparison with uninfected controls: a nationwide population-based study in South Korea. HIV Med 22(9):824-833. https://doi.org/10.1111/hiv.13139

4. Marcus JL, Leyden WA, Alexeeff SE, Anderson AN, Hechter RC, $\mathrm{Hu} \mathrm{H}$ et al (2020) Comparison of overall and comorbidity-free life expectancy between insured adults with and without HIV infection, 2000-2016. JAMA Netw Open 3(6):e207954. https:// doi.org/10.1001/jamanetworkopen.2020.7954

5. Shiau S, Broun EC, Arpadi SM, Yin MT (2013) Incident fractures in HIV-infected individuals: a systematic review and metaanalysis. AIDS 27(12):1949-1957. https://doi.org/10.1097/QAD. 0b013e328361d241

6. Dong HV, Cortés YI, Shiau S, Yin MT (2014) Osteoporosis and fractures in $\mathrm{HIV} /$ hepatitis $\mathrm{C}$ virus coinfection: a systematic review and meta-analysis. AIDS 28(14):2119-2131. https://doi. org/10.1097/qad.0000000000000363

7. O’Neill TJ, Rivera L, Struchkov V, Zaheen A, Thein HH (2014) The effect of HIV-hepatitis C co-infection on bone mineral density and fracture: a meta-analysis. PLoS ONE 9(7):e101493. https://doi.org/10.1371/journal.pone.0101493

8. Ilha T, Comim FV, Copes RM, Compston JE, Premaor MO (2018) HIV and vertebral fractures: a systematic review and metanalysis. Sci Rep 8(1):7838. https://doi.org/10.1038/ s41598-018-26312-9

9. Pramukti I, Lindayani L, Chen YC, Yeh CY, Tai TW, Fetzer $S$ et al (2020) Bone fracture among people living with HIV: a systematic review and meta-regression of prevalence, incidence, and risk factors. PLoS ONE 15(6):e0233501. https://doi.org/10. 1371/journal.pone.0233501

10. Starup-Linde J, Rosendahl SB, Storgaard M, Langdahl B (2020) Management of osteoporosis in patients living with HIV-A systematic review and meta-analysis. J Acquir Immune Defic Syndr 83(1):1-8. https://doi.org/10.1097/qai.0000000000002207

11. Chang CJ, Chan YL, Pramukti I, Ko NY, Tai TW (2021) People with HIV infection had lower bone mineral density and increased fracture risk: a meta-analysis. Arch Osteoporos 16(1):47. https:// doi.org/10.1007/s11657-021-00903-y

12. Sharma A, Shi Q, Hoover DR, Anastos K, Tien PC, Young MA et al (2015) Increased fracture incidence in middle-aged HIVinfected and HIV-uninfected women: updated results from the women's interagency HIV study. J Acquir Immune Defic Syndr 70(1):54-61. https://doi.org/10.1097/qai.0000000000000674

13. Gonciulea A, Wang R, Althoff KN, Palella FJ, Lake J, Kingsley LA et al (2017) An increased rate of fracture occurs a decade earlier in HIV+ compared with HIV- men. AIDS 31(10):14351443. https://doi.org/10.1097/QAD.0000000000001493

14. Jespersen NA, Axelsen F, Dollerup J, Nørgaard M, Larsen CS (2021) The burden of non-communicable diseases and mortality in people living with HIV (PLHIV) in the pre-, early- and late-HAART era. HIV Med 22(6):478-490. https://doi.org/10. 1111/hiv.13077

15. Zhang T, Wilson IB, Zullo AR, Meyers DJ, Lee Y, Daiello LA et al (2021) Hip fracture rates in nursing home residents with and without HIV. J Am Med Dir Assoc. https://doi.org/ 10.1016/j.jamda.2021.08.040

16. Byrne DD, Newcomb CW, Carbonari DM, Nezamzadeh MS, Leidl KB, Herlim M et al (2015) Increased risk of hip fracture associated with dually treated HIV/hepatitis B virus coinfection. J Viral Hepat 22(11):936-947. https://doi.org/10.1111/ jvh. 12398

17. Battalora L, Armon C, Palella F, Li J, Overton ET, Hammer J et al (2021) Incident bone fracture and mortality in a large HIV cohort outpatient study, 2000-2017, USA. Arch Osteoporos 16(1):117. https://doi.org/10.1007/s11657-021-00949-y

18. Goh SSL, Lai PSM, Tan ATB, Ponnampalavanar S (2018) Reduced bone mineral density in human immunodeficiency virus-infected individuals: a meta-analysis of its prevalence and risk factors. Osteoporos Int 29(3):595-613. https://doi.org/ 10.1007/s00198-017-4305-8

19. Gregson CL, Madanhire T, Rehman A, Ferrand RA, Cappola AR, Tollman S et al (2021) Osteoporosis, rather than 
sarcopenia, is the predominant musculoskeletal disease in a rural South African community where HIV prevalence is high: a cross-sectional study. J Bone Miner Res. https://doi.org/10. 1002/jbmr.4464

20. Rukuni R, Rehman AM, Mukwasi-Kahari C, Madanhire T, Kowo-Nyakoko F, McHugh G et al (2021) Effect of HIV infection on growth and bone density in peripubertal children in the era of antiretroviral therapy: a cross-sectional study in Zimbabwe. Lancet Child Adolesc Health 5(8):569-581. https://doi.org/ 10.1016/s2352-4642(21)00133-4

21. Bolland MJ, Grey A, Reid IR (2015) Skeletal health in adults with HIV infection. Lancet Diabetes Endocrinol 3(1):63-74. https://doi.org/10.1016/S2213-8587(13)70181-5

22. Hoy JF, Grund B, Roediger M, Schwartz AV, Shepherd J, Avihingsanon A et al (2017) Immediate initiation of antiretroviral therapy for HIV infection accelerates bone loss relative to deferring therapy: findings from the START bone mineral density substudy, a randomized trial. J Bone Miner Res 32(9):1945-1955. https://doi.org/10.1002/jbmr.3183

23. Guo F, Song X, Li Y, Guan W, Pan W, Yu W et al (2021) Longitudinal change in bone mineral density among Chinese individuals with HIV after initiation of antiretroviral therapy. Osteoporos Int 32(2):321-332. https://doi.org/10.1007/s00198-020-05584-w

24. Han WM, Wattanachanya L, Apornpong T, Jantrapakde J, Avihingsanon A, Kerr SJ et al (2020) Bone mineral density changes among people living with HIV who have started with TDFcontaining regimen: a five-year prospective study. PLoS ONE 15(3):e0230368. https://doi.org/10.1371/journal.pone.0230368

25. Biver E, Calmy A, Delhumeau C, Durosier C, Zawadynski S, Rizzoli R (2014) Microstructural alterations of trabecular and cortical bone in long-term HIV-infected elderly men on successful antiretroviral therapy. AIDS 28(16):2417-2427

26. Warming $L$ et al (2002) Changes in bone mineral density with age in men and women: a longitudinal study. Osteoporos Int 13(2):105-112

27. Khosla S et al (2005) Pathophysiology of age-related bone loss and osteoporosis. Endocrinol Metab Clin North Am 34(4):1015-1030

28. Finkelstein JS et al (2008) Bone mineral density changes during the menopause transition in a multiethnic cohort of women. J Clin Endocrinol Metab 93:861-868

29. Gnant $M$ et al (2015) Adjuvant denosumab in breast cancer (ABCSG-18): a multicentre, randomised, double-blind, placebo-controlled trial. Lancet 386:433-443

30. Gnant $M$ et al (2008) Adjuvant endocrine therapy plus zoledronic acid in premenopausal women with early-stage breast cancer: 5-year follow-up of the ABCSG-12 bone-mineral density substudy. Lancet Oncol 9:840-849

31. Messina OD et al (2021) Management of glucocorticoidinduced osteoporosis. Aging Clin Exp Res 33(4):793-804

32. Baranek B et al (2020) The effect of tenofovir disoproxil fumarate on bone mineral density: a systematic review and metaanalysis. Antivir Ther 25(1):21-32

33. Yin MT, Lund E, Shah J, Zhang CA, Foca M, Neu N et al (2014) Lower peak bone mass and abnormal trabecular and cortical microarchitecture in young men infected with HIV early in life. AIDS 28(3):345-353. https://doi.org/10.1097/qad. 0000000000000070

34. Calmy A, Chevalley T, Delhumeau C, Toutous-Trellu L, Spycher-Elbes R, Ratib O et al (2013) Long-term HIV infection and antiretroviral therapy are associated with bone microstructure alterations in premenopausal women. Osteoporos Int 24(6): 1843-1852. https://doi.org/10.1007/s00198-012-2189-1

35. Sellier P, Ostertag A, Collet C, Trout H, Champion K, Fernandez $\mathrm{S}$ et al (2016) Disrupted trabecular bone micro-architecture in middle-aged male HIV-infected treated patients. HIV Med 17(7):550-556. https://doi.org/10.1111/hiv.12380

36. Macdonald HM, Maan EJ, Berger C, Dunn RA, Côté HCF, Murray MCM et al (2020) Deficits in bone strength, density and microarchitecture in women living with HIV: a cross-sectional HR-pQCT study. Bone 138:115509. https://doi.org/10. 1016/j.bone.2020.115509

37. Yin MT, Shu A, Zhang CA, Boutroy S, McMahon DJ, Ferris DC et al (2013) Trabecular and cortical microarchitecture in postmenopausal HIV-infected women. Calcif Tissue Int 92(6):557-565. https://doi.org/10.1007/s00223-013-9716-8

38. Serrano S, Mariñoso ML, Soriano JC, Rubiés-Prat J, Aubia J, Coll J et al (1995) Bone remodelling in human immunodeficiency virus-1-infected patients. A histomorphometric study. Bone 16(2):185-191. https://doi.org/10.1016/8756-3282(94) 00028-X

39. Ramalho J, Martins CSW, Galvão J, Furukawa LN, Domingues WV, Oliveira IB et al (2019) Treatment of human immunodeficiency virus infection with tenofovir disoproxil fumaratecontaining antiretrovirals maintains low bone formation rate, but increases osteoid volume on bone histomorphometry. J Bone Miner Res 34(9):1574-1584. https://doi.org/10.1002/ jbmr.3751

40. Biver E, Calmy A, Rizzoli R (2017) Bone health in HIV and hepatitis B or C infections. Ther Adv Musculoskelet Dis 9(1):22-34. https://doi.org/10.1177/1759720X16671927

41. Maffezzoni F, Porcelli T, Delbarba A, Pezzaioli LC, Properzi M, Cappelli C et al (2020) Hypogonadism and bone health in men with HIV. Lancet HIV 7(11):e782-e790. https://doi.org/ 10.1016/s2352-3018(20)30236-8

42. Sharma A, Hoover DR, Shi Q, Tien PC, Weber KM, Shah JG et al (2021) HIV and menopause are independently associated with lower bone mineral density: results from the women's interagency HIV study. Clin Infect Dis. https://doi.org/10. 1093/cid/ciab874

43. Foreman SC, Wu PH, Kuang R, John MD, Tien PC, Link TM et al (2020) Factors associated with bone microstructural alterations assessed by HR-pQCT in long-term HIV-infected individuals. Bone 133:115210. https://doi.org/10.1016/j.bone. 2019.115210

44. Womack JA, Murphy TE, Ramsey C, Bathulapalli H, Leo-Summers L, Smith AC et al (2021) Brief report: are serious falls associated with subsequent fragility fractures among veterans living with HIV? J Acquir Immune Defic Syndr 88(2):192196. https://doi.org/10.1097/qai.0000000000002752

45. Mascarau R, Bertrand F, Labrousse A, Gennero I, Poincloux R, Maridonneau-Parini I et al (2020) HIV-1-infected human macrophages, by secreting RANK-L, contribute to enhanced osteoclast recruitment. Int J Mol Sci. https://doi.org/10.3390/ijms2 1093154

46. Delpino MV, Quarleri J (2020) Influence of HIV infection and antiretroviral therapy on bone homeostasis. Front Endocrinol (Lausanne) 11:502. https://doi.org/10.3389/fendo.2020.00502

47. Raynaud-Messina B, Bracq L, Dupont M, Souriant S, Usmani SM, Proag A et al (2018) Bone degradation machinery of osteoclasts: an HIV-1 target that contributes to bone loss. Proc Natl Acad Sci U S A 115(11):E2556-E2565. https://doi.org/10.1073/ pnas. 1713370115

48. Ofotokun I, Titanji K, Vikulina T, Roser-Page S, Yamaguchi M, Zayzafoon M et al (2015) Role of T-cell reconstitution in HIV-1 antiretroviral therapy-induced bone loss. Nat Commun 6:8282. https://doi.org/10.1038/ncomms9282

49. Ofotokun I, Titanji K, Vunnava A, Roser-Page S, Vikulina T, Villinger F et al (2016) Antiretroviral therapy induces a rapid increase in bone resorption that is positively associated with the 
magnitude of immune reconstitution in HIV infection. AIDS 30(3):405-414. https://doi.org/10.1097/qad.0000000000000918

50. Ogbuagu O, Ruane PJ, Podzamczer D, Salazar LC, Henry K, Asmuth DM et al (2021) Long-term safety and efficacy of emtricitabine and tenofovir alafenamide vs emtricitabine and tenofovir disoproxil fumarate for HIV-1 pre-exposure prophylaxis: week 96 results from a randomised, double-blind, placebo-controlled, phase 3 trial. Lancet HIV 8(7):e397-e407. https://doi.org/10. 1016/s2352-3018(21)00071-0

51. Mayer KH, Molina JM, Thompson MA, Anderson PL, Mounzer $\mathrm{KC}$, De Wet JJ et al (2020) Emtricitabine and tenofovir alafenamide vs emtricitabine and tenofovir disoproxil fumarate for HIV pre-exposure prophylaxis (DISCOVER): primary results from a randomised, double-blind, multicentre, active-controlled, phase 3, non-inferiority trial. Lancet 396(10246):239-254. https://doi. org/10.1016/s0140-6736(20)31065-5

52. McComsey GA, Lupo S, Parks D, Poggio MC, De Wet J, Kahl LP et al (2018) Switch from tenofovir disoproxil fumarate combination to dolutegravir with rilpivirine improves parameters of bone health. AIDS 32(4):477-485. https://doi.org/10.1097/qad. 0000000000001725

53. Maggiolo F, Rizzardini G, Raffi F, Pulido F, Mateo-Garcia MG, Molina JM et al (2019) Bone mineral density in virologically suppressed people aged 60 years or older with HIV-1 switching from a regimen containing tenofovir disoproxil fumarate to an elvitegravir, cobicistat, emtricitabine, and tenofovir alafenamide single-tablet regimen: a multicentre, open-label, phase $3 \mathrm{~b}$, randomised trial. Lancet HIV 6(10):e655-e666. https://doi.org/10. 1016/s2352-3018(19)30195-x

54. Nishijima T, Mutoh Y, Kawasaki Y, Tomonari K, Kikuchi Y, Gatanaga $\mathrm{H}$ et al (2018) Cumulative exposure of TDF is associated with kidney tubulopathy whether it is currently used or discontinued. AIDS 32(2):179-188. https://doi.org/10.1097/qad. 0000000000001667

55. Gupta SK, Post FA, Arribas JR, Eron JJ Jr, Wohl DA, Clarke AE et al (2019) Renal safety of tenofovir alafenamide vs. tenofovir disoproxil fumarate: a pooled analysis of 26 clinical trials. AIDS 33(9):1455-1465. https://doi.org/10.1097/qad.00000 00000002223

56. Shukla S, Kumari S, Bal SK, Monaco DC, Ribeiro SP, Sekaly RP et al (2021) "Go", "No Go," or "Where to Go"; does microbiota dictate T cell exhaustion, programming, and HIV persistence? Curr Opin HIV AIDS 16(4):215-222. https://doi.org/10.1097/ coh.0000000000000692

57. Imahashi $\mathrm{M}$, Ode $\mathrm{H}$, Kobayashi A, Nemoto $\mathrm{M}$, Matsuda $\mathrm{M}$, Hashiba C et al (2021) Impact of long-term antiretroviral therapy on gut and oral microbiotas in HIV-1-infected patients. Sci Rep 11(1):960. https://doi.org/10.1038/s41598-020-80247-8

58. Dubé MP, Park SY, Ross H, Love TMT, Morris SR, Lee HY (2018) Daily HIV pre-exposure prophylaxis (PrEP) with tenofovir disoproxil fumarate-emtricitabine reduced Streptococcus and increased Erysipelotrichaceae in rectal microbiota. Sci Rep 8(1):15212. https://doi.org/10.1038/s41598-018-33524-6

59. Fulcher JA, Li F, Cook RR, Zabih S, Louie A, Okochi H et al (2019) Rectal microbiome alterations associated with oral human immunodeficiency virus pre-exposure prophylaxis. Open Forum Infect Dis 6(11):ofz463. https://doi.org/10.1093/ ofid/ofz463

60. Perler BK, Reinhart EM, Montgomery M, Maynard M, Shapiro JM, Belenky P et al (2021) Evaluation of the microbiome in men taking pre-exposure prophylaxis for HIV prevention. AIDS Behav 25(7):2005-2013. https://doi.org/10.1007/ s10461-020-03130-7

61. Maier L, Pruteanu M, Kuhn M, Zeller G, Telzerow A, Anderson EE et al (2018) Extensive impact of non-antibiotic drugs on human gut bacteria. Nature 555(7698):623-628. https://doi.org/ 10.1038/nature25979

62. Biver E, Calmy A, Aubry-Rozier B, Birkhauser M, BischoffFerrari HA, Ferrari S et al (2019) Diagnosis, prevention, and treatment of bone fragility in people living with HIV: a position statement from the Swiss Association against Osteoporosis. Osteoporos Int 30(5):1125-1135. https://doi.org/10.1007/ s00198-018-4794-0

63. Brown TT, Hoy J, Borderi M, Guaraldi G, Renjifo B, Vescini F et al (2015) Recommendations for evaluation and management of bone disease in HIV. Clin Infect Dis 60(8):1242-1251. https:// doi.org/10.1093/cid/civ010

64. Yin MT, Shiau S, Rimland D, Gibert CL, Bedimo RJ, RodriguezBarradas MC et al (2016) Fracture prediction with modifiedFRAX in older HIV-infected and uninfected men. J Acquir Immune Defic Syndr 72(5):513-520. https://doi.org/10.1097/ QAI.0000000000000998

65. Yang J, Sharma A, Shi Q, Anastos K, Cohen MH, Golub ET et al (2018) Improved fracture prediction using different fracture risk assessment tool adjustments in HIV-infected women. AIDS 32(12):1699-1706. https://doi.org/10.1097/qad.0000000000 001864

66. Mansueto P, Seidita A, Vitale G, Gangemi S, Iaria C, Cascio A (2015) Vitamin D deficiency in HIV infection: not only a bone disorder. Biomed Res Int 2015:735615. https://doi.org/10.1155/ 2015/735615

67. EACS (2021) European AIDS Clinical Society guidelines. Version 11.0 October 2021. http://www.eacsociety.org/guidelines/ eacs-guidelines/eacs-guidelines.html.

68. Alvarez N, Aguilar-Jimenez W, Rugeles MT (2019) The potential protective role of vitamin D supplementation on HIV-1 infection. Front Immunol 10:2291. https://doi.org/10.3389/fimmu.2019. 02291

69. Rizzoli R, Boonen S, Brandi ML, Bruyère $\mathrm{O}$, Cooper $\mathrm{C}$, Kanis JA et al (2013) Vitamin D supplementation in elderly or postmenopausal women: a 2013 update of the 2008 recommendations from the European Society for Clinical and Economic Aspects of Osteoporosis and Osteoarthritis (ESCEO). Curr Med Res Opin 29(4):305-313. https://doi.org/10.1185/03007995.2013.766162

70. Havens PL, Stephensen CB, Hazra R, Flynn PM, Wilson CM, Rutledge B et al (2012) Vitamin D3 decreases parathyroid hormone in HIV-infected youth being treated with tenofovir: a randomized, placebo-controlled trial. Clin Infect Dis 54(7):10131025. https://doi.org/10.1093/cid/cir968

71. Giacomet V, Vigano A, Manfredini V, Cerini C, Bedogni G, Mora S et al (2013) Cholecalciferol supplementation in HIVinfected youth with vitamin D insufficiency: effects on vitamin D status and T-cell phenotype: a randomized controlled trial. HIV Clin Trials 14(2):51-60. https://doi.org/10.1310/hct1402-51

72. Havens PL, Stephensen CB, Van Loan MD, Schuster GU, Woodhouse LR, Flynn PM et al (2018) Vitamin D3 supplementation increases spine bone mineral density in adolescents and young adults with human immunodeficiency virus infection being treated with tenofovir disoproxil fumarate: a randomized, placebo-controlled trial. Clin Infect Dis 66(2):220-228. https://doi. org/10.1093/cid/cix753

73. Sudjaritruk T, Bunupuradah T, Aurpibul L, Kanjanavanit S, Chotecharoentanan T, Sricharoen N et al (2021) Impact of vitamin D and calcium supplementation on bone mineral density and bone metabolism among thai adolescents with perinatally acquired human immunodeficiency virus (HIV) infection: a randomized clinical trial. Clin Infect Dis 73(9):1555-1564. https://doi.org/ 10.1093/cid/ciab547

74. Overton ET, Chan ES, Brown TT, Tebas P, McComsey GA, Melbourne KM et al (2015) Vitamin D and calcium attenuate bone 
loss with antiretroviral therapy initiation: a randomized trial. Ann Intern Med 162(12):815-824. https://doi.org/10.7326/M14-1409

75. Havers FP, Detrick B, Cardoso SW, Berendes S, Lama JR, Sugandhavesa $P$ et al (2014) Change in vitamin d levels occurs early after antiretroviral therapy initiation and depends on treatment regimen in resource-limited settings. PLoS ONE 9(4):e95164. https://doi.org/10.1371/journal.pone.0095164

76. Wohl DA, Orkin C, Doroana M, Pilotto JH, Sungkanuparph S, Yeni $P$ et al (2014) Change in vitamin D levels and risk of severe vitamin D deficiency over 48 weeks among HIV-1-infected, treatment-naive adults receiving rilpivirine or efavirenz in a Phase III trial (ECHO). Antivir Ther 19(2):191-200. https://doi.org/10. 3851/IMP2721

77. Arpadi SM, McMahon DJ, Abrams EJ, Bamji M, Purswani M, Engelson ES et al (2012) Effect of supplementation with cholecalciferol and calcium on 2-y bone mass accrual in HIV-infected children and adolescents: a randomized clinical trial. Am J Clin Nutr 95(3):678-685. https://doi.org/10.3945/ajen.111.024786

78. Rovner AJ, Stallings VA, Rutstein R, Schall JI, Leonard MB, Zemel BS (2017) Effect of high-dose cholecalciferol (vitamin $\mathrm{D}(3)$ ) on bone and body composition in children and young adults with HIV infection: a randomized, double-blind, placebocontrolled trial. Osteoporos Int 28(1):201-209. https://doi.org/ 10.1007/s00198-016-3826-x

79. Eckard AR, Oriordan MA, Rosebush JC, Ruff JH, Chahroudi A, Labbato D et al (2017) Effects of vitamin D supplementation on bone mineral density and bone markers in HIV-infected youth. J Acquir Immune Defic Syndr 76(5):539-546. https://doi.org/10. 1097/qai.0000000000001545

80. Bang UC, Kolte L, Hitz M, Schierbeck LL, Nielsen SD, Benfield T et al (2013) The effect of cholecalciferol and calcitriol on biochemical bone markers in HIV type 1-infected males: results of a clinical trial. AIDS Res Hum Retroviruses 29(4):658-664. https://doi.org/10.1089/aid.2012.0263

81. Yin MT, RoyChoudhury A, Bucovsky M, Colon I, Ferris DC, Olender S et al (2019) A randomized placebo-controlled trial of low- versus moderate-dose vitamin D3 supplementation on bone mineral density in postmenopausal women with HIV. J Acquir Immune Defic Syndr 80(3):342-349. https://doi.org/10.1097/qai. 0000000000001929

82. Bolland MJ, Grey A, Horne AM, Briggs SE, Thomas MG, EllisPegler RB et al (2012) Effects of intravenous zoledronate on bone turnover and bone density persist for at least five years in HIV-infected men. J Clin Endocrinol Metab 97(6):1922-1928. https://doi.org/10.1210/jc.2012-1424

83. Negredo E, Bonjoch A, Pérez-Álvarez N, Ornelas A, Puig J, Herrero C et al (2015) Comparison of two different strategies of treatment with zoledronate in HIV-infected patients with low bone mineral density: single dose versus two doses in 2 years. HIV Med 16(7):441-448. https://doi.org/10.1111/hiv.12260

84. Ofotokun I, Titanji K, Lahiri CD, Vunnava A, Foster A, Sanford SE et al (2016) A single-dose zoledronic acid infusion prevents antiretroviral therapy-induced bone loss in treatmentnaive hiv-infected patients: a phase IIb trial. Clin Infect Dis 63(5):663-671. https://doi.org/10.1093/cid/ciw331

85. McGinty T, Alvarez-Barco E, Tinago W, Macken A, O'Broin C, Cotter AG, et al (2021) Short-course alendronate for the prevention of ART-associated bone loss. In: [CROI Abstract 96]. Abstracts from the virtual CROI 2021 conference on retroviruses and opportunistic infections. vCROI 2021 Abstract eBook. 2021;483.

86. Makras P, Petrikkos P, Anastasilakis AD, Kolynou A, Katsarou A, Tsachouridou O et al (2021) Denosumab versus zoledronate for the treatment of low bone mineral density in male HIV-infected patients. Bone Rep 15:101128. https://doi.org/10. 1016/j.bonr.2021.101128
87. Guaraldi G, Orlando G, Madeddu G, Vescini F, Ventura P, Campostrini $S$ et al (2004) Alendronate reduces bone resorption in HIV-associated osteopenia/osteoporosis. HIV Clin Trials 5(5):269-277. https://doi.org/10.1310/md8v-5dlg-en3t-brhx

88. Negredo E, Martínez-López E, Paredes R, Rosales J, Pérez-Alvarez N, Holgado S et al (2005) Reversal of HIV-1-associated osteoporosis with once-weekly alendronate. AIDS 19(3):343-345

89. Mondy K, Powderly WG, Claxton SA, Yarasheski KH, Royal M, Stoneman JS et al (2005) Alendronate, vitamin D, and calcium for the treatment of osteopenia/osteoporosis associated with HIV infection. J Acquir Immune Defic Syndr 38(4):426-431. https:// doi.org/10.1097/01.qai.0000145352.04440.1e

90. McComsey GA, Kendall MA, Tebas P, Swindells S, Hogg E, Alston-Smith B et al (2007) Alendronate with calcium and vitamin D supplementation is safe and effective for the treatment of decreased bone mineral density in HIV. AIDS 21(18):24732482. https://doi.org/10.1097/QAD.0b013e3282ef961d

91. Rozenberg S, Lanoy E, Bentata M, Viard JP, Valantin MA, Missy $P$ et al (2012) Effect of alendronate on HIV-associated osteoporosis: a randomized, double-blind, placebo-controlled, 96-week trial (ANRS 120). AIDS Res Hum Retroviruses 28(9):972-980. https://doi.org/10.1089/aid.2011.0224

92. Jacobson DL, Lindsey JC, Gordon C, Hazra R, Spiegel H, Ferreira $\mathrm{F}$ et al (2020) Alendronate improves bone mineral density in children and adolescents perinatally infected with human immunodeficiency virus with low bone mineral density for age. Clin Infect Dis 71(5):1281-1288. https://doi.org/10.1093/cid/ciz957

93. Lindsey JC, Jacobson DL, Spiegel HM, Gordon CM, Hazra R, Siberry GK (2021) Safety and efficacy of 48 and 96 weeks of alendronate in children and adolescents with perinatal human immunodeficiency virus infection and low bone mineral density for age. Clin Infect Dis 72(6):1059-1063. https://doi.org/10. 1093/cid/ciaa861

94. Bolland MJ, Grey AB, Horne AM, Briggs SE, Thomas MG, Ellis-Pegler RB et al (2007) Annual zoledronate increases bone density in highly active antiretroviral therapy-treated human immunodeficiency virus-infected men: a randomized controlled trial. J Clin Endocrinol Metab 92(4):1283-1288. https://doi.org/ 10.1210/jc.2006-2216

95. Bolland MJ, Grey AB, Horne AM, Briggs SE, Thomas MG, Ellis-Pegler RB et al (2008) Effects of intravenous zoledronate on bone turnover and BMD persist for at least 24 months. J Bone Miner Res 23(8):1304-1308. https://doi.org/10.1359/jbmr. 080312

96. Huang J, Meixner L, Fernandez S, McCutchan JA (2009) A double-blinded, randomized controlled trial of zoledronate therapy for HIV-associated osteopenia and osteoporosis. AIDS 23(1):51-57. https://doi.org/10.1097/QAD.0b013e32831c8adc

97. Hoy JF, Richardson R, Ebeling PR, Rojas J, Pocock N, Kerr SJ et al (2018) Zoledronic acid is superior to tenofovir disoproxil fumarate-switching for low bone mineral density in adults with HIV. AIDS 32(14):1967-1975. https://doi.org/10.1097/qad. 0000000000001911

98. Carr A, Kerr SJ, Richardson R, Ebeling P, Pocock N, Rojas J et al (2019) Prolonged effect of zoledronic acid on bone mineral density and turnover in HIV-infected adults on tenofovir: a randomized. Open-Label Study J Bone Miner Res 34(12):2192-2197. https://doi.org/10.1002/jbmr.3834

99. Lei JJH, Pereira B, Moyle G, Boffito M, Milinkovic A (2021) The benefits of tenofovir discontinuation with or without bisphosphonate therapy in osteoporotic people living with HIV. HIV Med 22(9):816-823. https://doi.org/10.1111/hiv.13137

100. Venter WDF, Sokhela S, Simmons B, Moorhouse M, Fairlie L, Mashabane N et al (2020) Dolutegravir with emtricitabine and tenofovir alafenamide or tenofovir disoproxil fumarate versus efavirenz, emtricitabine, and tenofovir disoproxil fumarate 
for initial treatment of HIV-1 infection (ADVANCE): week 96 results from a randomised, phase 3, non-inferiority trial. Lancet HIV 7(10):e666-e676. https://doi.org/10.1016/s2352-3018(20) 30241-1

101. Surial B, Mugglin C, Calmy A, Cavassini M, Günthard HF, Stöckle $\mathrm{M}$ et al (2021) Weight and metabolic changes after switching from tenofovir disoproxil fumarate to tenofovir alafenamide in people living with HIV: a cohort study. Ann Intern Med 174(6):758-767. https://doi.org/10.7326/m20-4853

Publisher's Note Springer Nature remains neutral with regard to jurisdictional claims in published maps and institutional affiliations. 